\title{
SUFISTIC INFLUENCE ON THE ARCHITECTURAL TYPOLOGY OF THE MELAKA TENGKERA MOSQUE OF MELAKA, MALAYSIA
}

\author{
AZIZI BAHAUDDIN \& HAKIMI AHMAD \\ School of Housing, Building and Planning, Universiti Sains Malaysia, Malaysia
}

\begin{abstract}
Islam grew rapidly in the Malay world at the end of the 13th and early 14th centuries AD. It was spread by missionaries from Arab countries, India, Iraq and China. It comes along with the teachings of Sufism or tasawwuf - Islamic esoteric dimensions supported and complemented by Islamic exoteric Sharia practice. The mosque becomes a sacred symbol of importance to this religion. The construction of the mosque since the time of Prophet Muhammad ( $p b u h)$ has shown a lot of changes. The typology of the Malay mosque architecture is of medium scale and has its contextual value reflecting the identity of the Sufis former leaders such as the influence of the high priest, or ulama, of the Wali Songo, the revered saints of Islam in Indonesia. The legacy of the Sufis must be maintained so as not to be marginalized by modernity and globalisation. These questions arose as many people believed that the majority of contemporary mosques no longer inherit the value of the traditional Wali Songo mosque. This opinion is quite reasonable due to the formal expression of the mosque today which is different from the traditional Wali Songo mosque. For example, the contemporary mosques are dominated by domes and towers, both of which are of monumental scale. They are two non-local elements that have replaced local parts and altered the official expressions of the mosques in the archipelago. It continued to fade after the colonial period despite the deeply rooted approach of Sufism that emerged 400 years ago. The Melaka Tengkera Mosque built in the 18th century AD still demonstrates its simplicity in terms of its scale and traditional image, as well as the value of hybrid assimilation or Hindu-Buddhist syncretism and tolerance. This article uses qualitative methods particularly in ethnographic and phenomenological approaches supported by architectural documentation in emphasising the symbolic and semiotic aesthetic expression aspects. This emotional bonding contributes to the Sufistic symbolic aesthetics in the mosque. The study found that the traditional architecture of the mosque still creates the sacred Sufistic ambience through its more civilised concept of spatial transitions, with a complete ritual experience of the heritage of the Wali Songo Sufis.
\end{abstract}

Keywords: Sufism, Philosophy, Mosque, Ethics and Aesthetics

\section{INTRODUCTION}

The term mosque also known as Bayt Allah or the house of God (Baitullah) brings the idea of worship and religion and the sole owner of this house is God (Allah). The concept of Baitullah further confirmed that the Ka'abah (Haram Mosque) in Mecca and the Al-Aqsa Mosque in Jerusalem were the first global contributions in Islamic architecture [1]. The Ka'abah became the qiblah (the direction of prayers towards Ka'abah) for Muslims' tawhid (belief of the Oneness of Allah) around the world which lasted more than 15 centuries. It has a universal concept that encompasses and overcomes the whole world of life and the hereafter [2]. Praying towards the Ka'abah in the form of prayers in purifying themselves ritualistically is one of the nuances of Sufism. These include dhikr (the rhythmic repetition chants in the name of Allah), prayers, zakat (alms), recitation of the Koran and Tawaf (circumambulations of the Ka'abah). All these rituals are tied to Nubuwwah's (exemplary person) historical concept, such as performing Umrah (the non-mandatory lesser pilgrimage) and Hajj (the greater Muslim pilgrimage to Mecca), the fifth pillar of Islam. In reference to the Ka'abah 
architecture, the value of philosophy and the concept of tasawwuf (the process of realising ethical and spiritual ideals) go beyond boundaries of reasons and feelings. This is because of the Ka'abah's privilege that contains the question of reality. The basic principle agreed upon by the scholars in the explanation of the fact that the reality is not nor cannot be known only by looking at and evaluating from the perspective related to its foundations. Among them is Sufism's religious experience and religious values related to the mosque. So what needs to be considered is the potential of the mosque associated with its accompaniment, its distinctive features such as its design, its function and its usefulness in society. The symbols and materials of the mosque are the manifestations of the foundations that reveal the accepted facts of Sufism [3].

\section{METHODOLOGY}

This study uses descriptive qualitative approaches, especially in the context of ethnography and phenomenology, with the aim of obtaining accurate systematic facts regarding the characteristics and values of expression from the typology of the Melaka Tengkera Mosque. According to Groat [4], qualitative methods have the power to interpret something behind the meaning of symbols and forms. This study begins with comparing the early documentation of typology of the mosque's evolution with observation of the typology of this mosque. The observation also focussed on the overall composition of the mosque space contained in the hybrid components of some mosque architectural design styles. However, this study concentrated only on some of the dominant components such as the appearance of the roof, the prayer room, the porch space, the ablution space and the azan (call for prayer) tower. The study also conducted several interviews with local residents, authorities and historical figures to understand more about the history and the philosophy of the mosque.

\section{HISTORY OF THE MOSQUE}

At the beginning of the life of the Prophet (pbuh), before the Hijrah year, the mosque was not a special building or a specific architectural work. According to the hadith narrated by Sahih Muslim:

Jabir Abdullah Al-Ansary reported that the Prophet had mentioned that the earth has been made sacred and pure and a mosque for me, so whenever the time of prayer comes for any one of you he should pray wherever he is.

Physically, the early building of the Masjid Nabawi (Prophet's Mosque) was a rectangular building using mud brick construction methods. The building had four walls and three protected areas. Roofs were supported by posts made of palm tree trunks. The first part of the roof protected the main space on the wall facing the qiblah. The second closed part was to protect the house of the Prophet Muhammad (pbuh) and his wives to the left of the main hall. The other side of the roof was located in front of the mosque where Sufis (al-suffah) spent their night. These were poor but educated immigrants. They learned from Prophet Muhammad (pbuh) and served him (Fig. 1).

A theory by Caetani quoted in Dickie [6] regarding the construction of Masjid Nabawi as supported by Creswell [5, 7] stated that this building was not a mosque. There were various cultural and welfare works held including military training, politics and economic activities and also a room for homeless people [8-10]. 


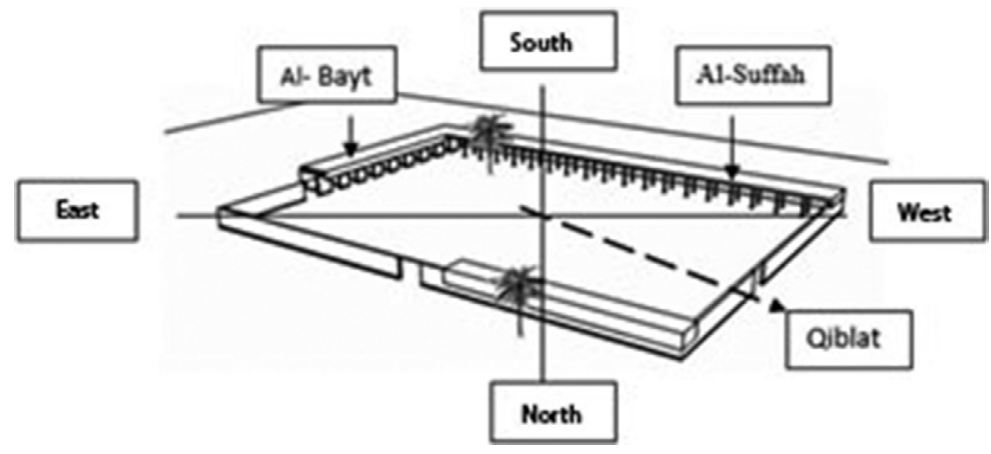

Figure 1: Masjid Nabawi complex [5].

\section{DEFINITION OF MOSQUE}

There are some definitions and terms of the mosque that are debated by scholars [11], which are related to the definition of mosques in terms of syara'/shari'a (law) and urf (general). In the Quran, this mosque is expressed in two terms. First, it refers to the place of worship of Muslims, in line with other religious places of worship such as churches and synagogues [12, 13]. As an example, in Bayt al-Muqqadis, the holy land for the three religions of IbrahimJudaism, Christianity and Islam. Second, the word bayt also shows two meanings. First, the word bayt Allah refers to the Baitullah of the Holy Mosque. Second, the word bayt refers to the home of the Prophet's family, as in the word of Allah (al-Ahzab: 33):

And stay in your home and do not go show your character as in Time of Ignorance. Establish Prayer, give alms, and obey Allah and His Messenger. Verily, Allah wants to remove your sins from you (ahlul-bayt) family members (Prophets), and purify you completely [14].

This verse proves the teachings of tasawwuf purify the soul, the nuance of Sufism characterised by the ahlul-bayt (the people of the house). The bayt word also refers to the animal' s nest (i.e. bees' nests (An-Nahl, 16:68) and spider's web (Al-Ankabut, 29:41)) and general terms (Fig. 2).

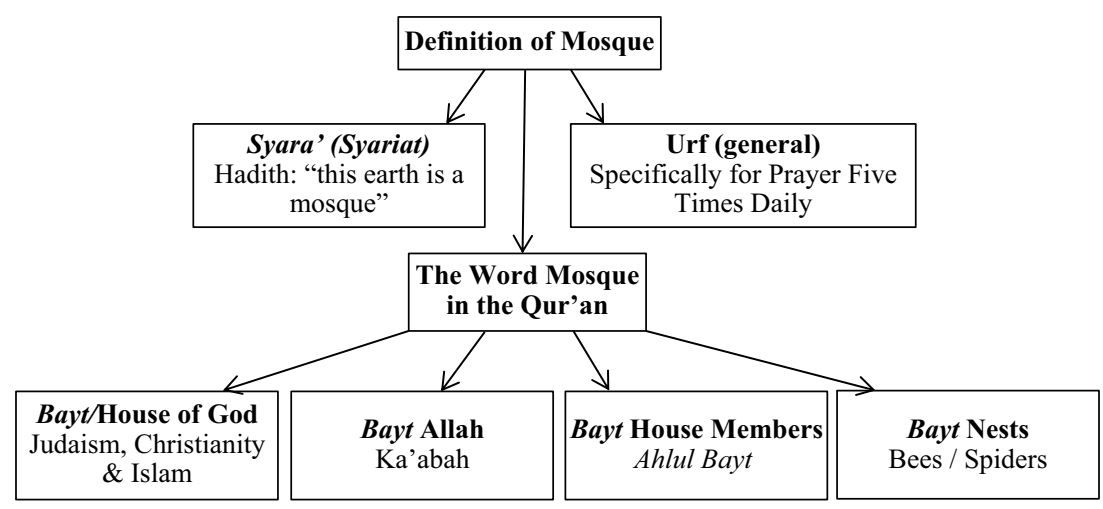

Figure 2: Mosque according to syara' and urf. 


\section{HISTORY OF THE MOSQUE IN MALAYSIA}

Melaka is one of the 14 states in Peninsular Malaysia (Fig. 3). It is located along the Straits of Melaka and was established in the 15th century. Melaka may have the most dominant position in Malaysian history. There are two categories of historical mosques that are distinctive in Malaysian Islamic architecture. The first is the vernacular influence that was believed to have formed when Islam first came to the Malay Archipelago. The second architectural style has been brought about by Western influences and categorised as Classical Islamic Forms. This style includes dome, gate and tower, believed to be derived from the Moghuls and Islamic Bengal [15]. This style was only built in Southeast Asia in the 19th century [16]. The vernacular mosque in the region was designed without a dome but rather a high roof that forms the most dominant feature. There are two types of vernacular mosques found in Malaysia. The first type has a stacked pyramid roof, which is sometimes referred to as a meru (mountain) and the second type has the same characteristics as traditional dwellings with long roofs. These two types were the earliest mosque typology in Malaysian history. On the contrary, there are two categories of vernacular mosques: one based on the traditional influences and the other was based on the regional influences. Traditional influences usually reflect the strong influence of the Malay home, but the affected mosque is similar to the old mosque built in many parts of Indonesia. This is true in the case of Melaka Tengkera Mosque.

The architectural style of this mosque has a direct influence from Java. It was brought through Sumatera during the Dutch occupation years. The style introduced new concepts to the Malay Peninsula [18]. The style and shape of the Javanese architecture spread to the Malay Peninsula, replacing the old wooden panels with stone walls, on a platform with low perimeter stone walls, to create a Melakan style. In the 15 th century AD, a pesantren (Sufi institution - religious boarding school) by Wali Songo was formed. It was said that Maulana Malik Ibrahim was the first Sufi figure to build a pesantren in Gresik, Java [19]. The Great Mosque of Demak built by Wali Songo in 1479 [20] was believed to have undergone many renovations and improvements (Fig. 4) and was understood as the oldest mosque in Southeast Asia. This mosque architecture became a typology that was once influenced by the mosque

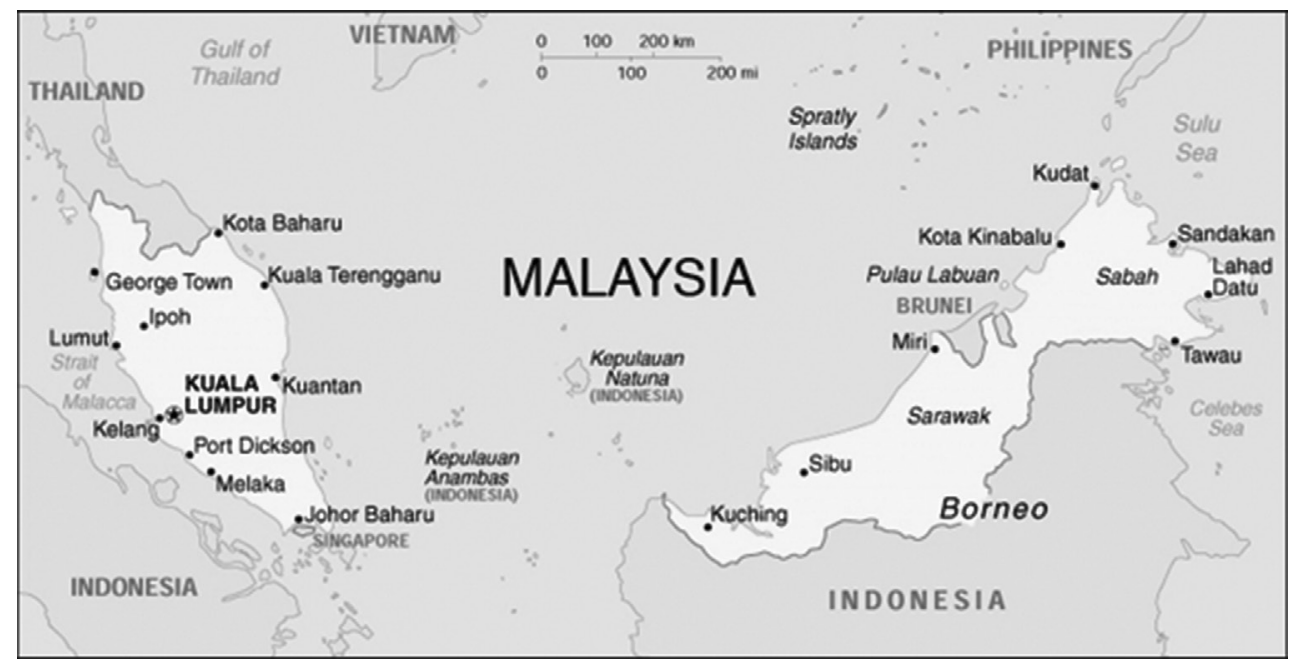

Figure 3: Peninsular Malaysia [17]. 


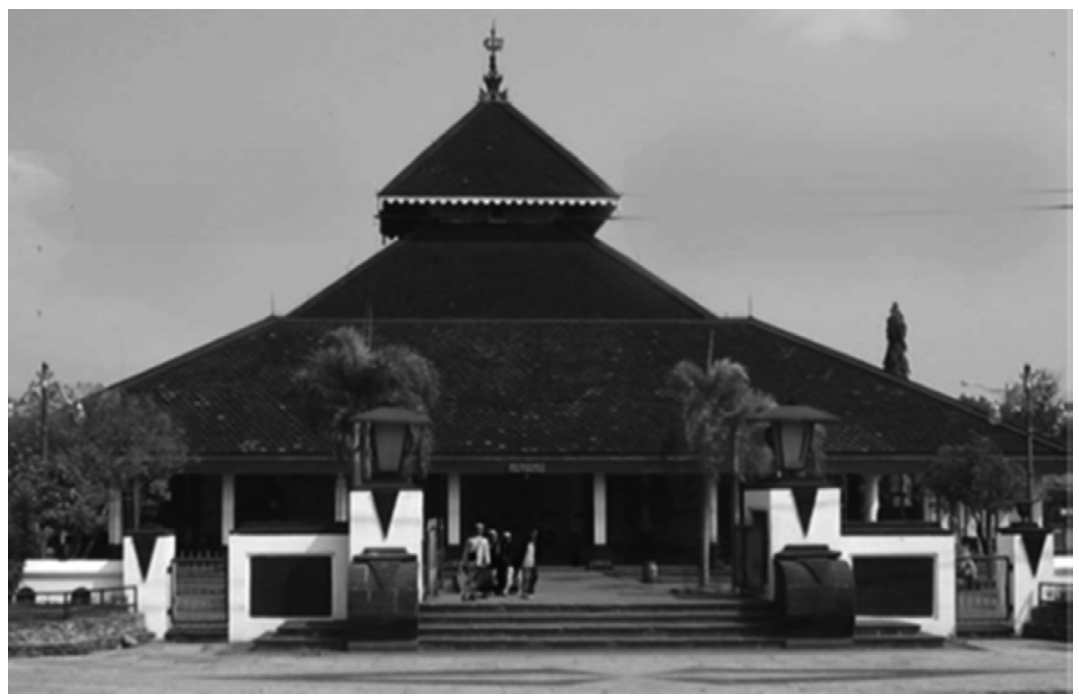

Figure 4: Demak Great Mosque, Indonesia [21].

architecture throughout the Malay Archipelago. The mosque is located in the middle of a walled area and is surrounded by a cemetery.

\section{THE MELAKA TENGKERA MOSQUE}

The Tengkera Mosque was built around 1728 [22] during the Dutch colonial era. It is located on Jalan Tengkera Melaka (Fig. 5) in the Tengkera area, $10 \mathrm{~km}$ to the northwest of the old Melaka town and considered as the oldest mosque in Melaka (Fig. 6). It used to be the Melaka

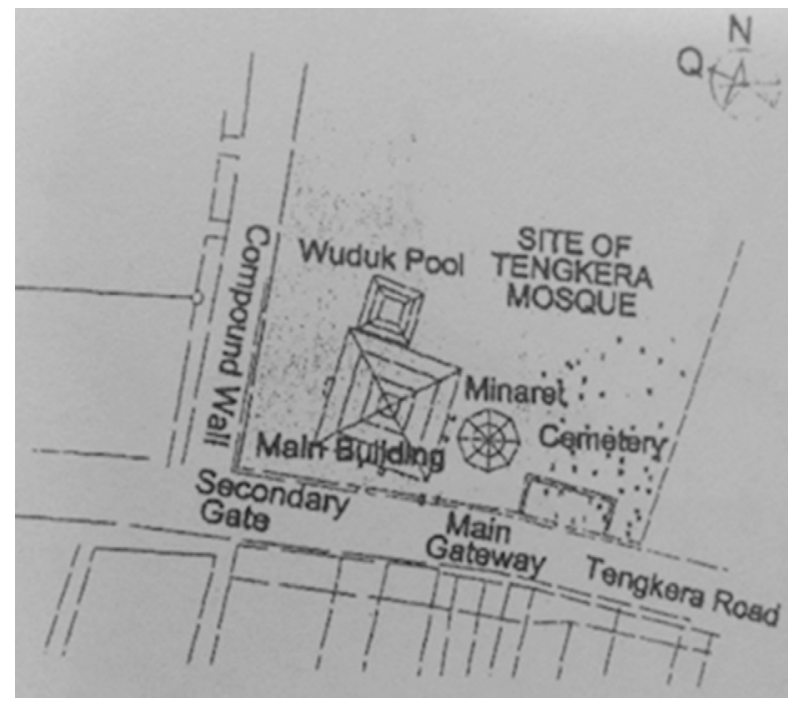

Figure 5: Mosque site plan [23]. 


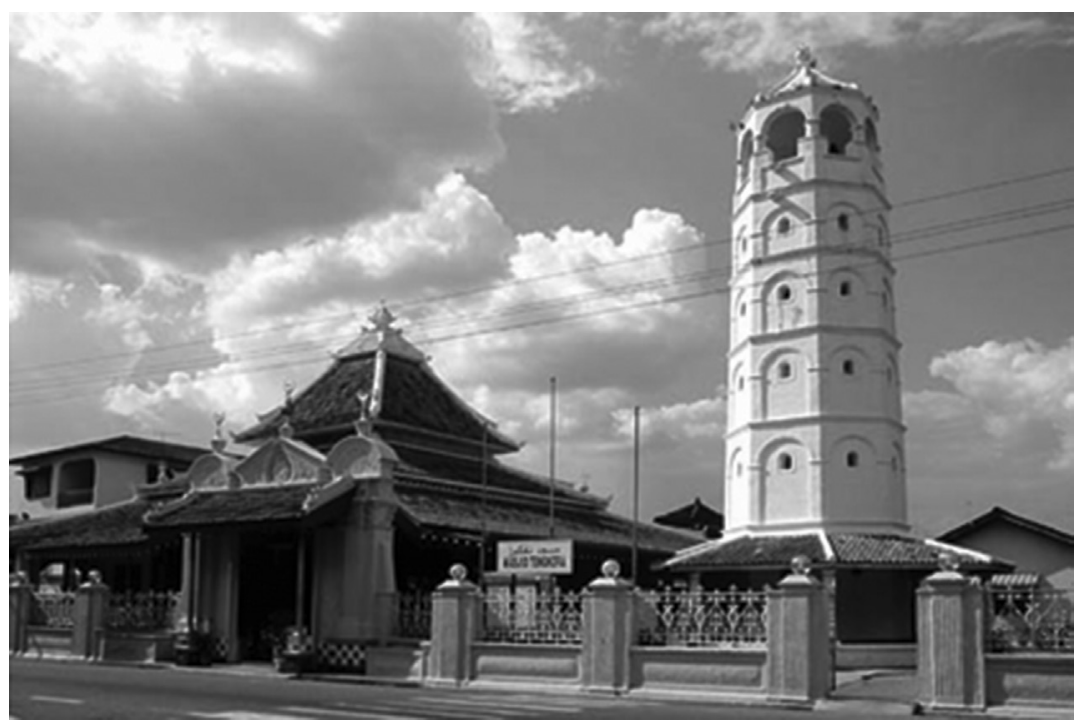

Figure 6: Tengkera mosque.

State Mosque. Originally, the mosque was made of wood with its roof constructed of coconut fronds and columns of Borneon ironwood imported from Kalimantan, Indonesia. The mosque was renovated twice in 1890 and in 1910. This traditional mosque is still standing in Melaka today, illustrating the architectural uniqueness of the Malay world with its everlasting construction technology. This design considered climate requirements integrating with space functions and mosque architectural elements that are essential in mosque design [9].

The main reference of the mosque was from the Masjid Nabawi design in Medina [24, 25] that featured space function and building orientation components such as qiblah (Fig. 7), main entrance (south west and south east), entrance from wudhu (ablution) pool (north east), prayer hall, mihrab (niche area) to show qiblah, mimbar (pulpit), main roof design, minaret

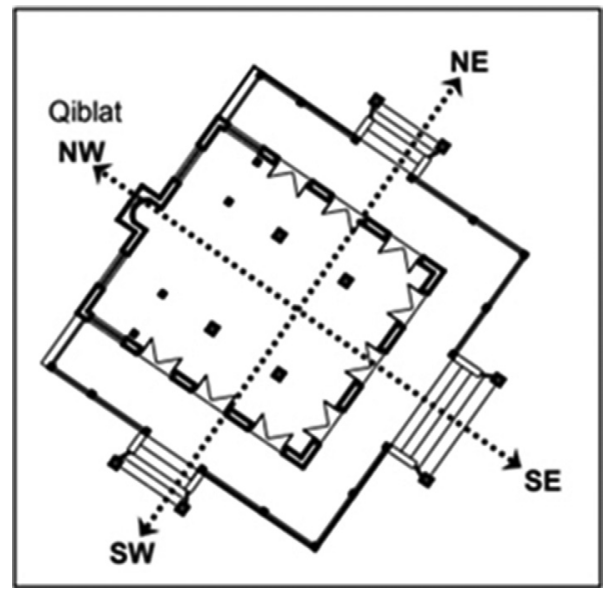

Figure 7: Qiblah orientation. 


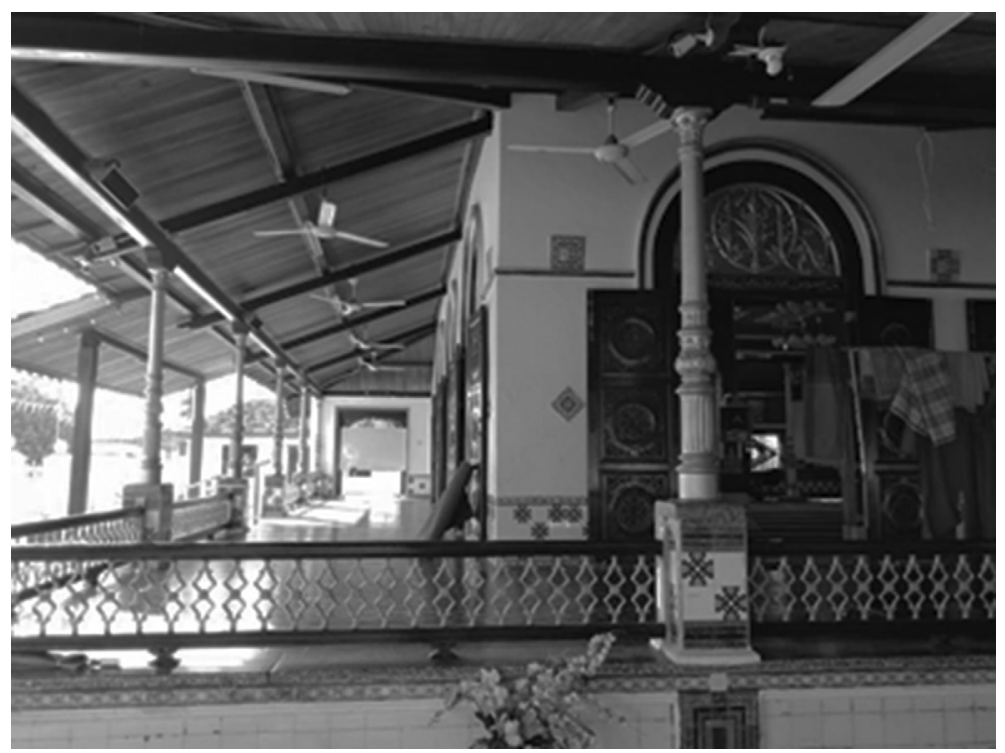

Figure 8: Serambi (veranda).

and cemetery (south east). The shape of the mosque is $18 \times 18 \mathrm{~m}^{2}$, with a small additional shape attached to it. The mosque is divided into several main areas such as prayer hall, mihrab (niche), porch and utility room. The main prayer hall is rectangular, measuring $15 \times 12 \mathrm{~m}$. A Serambi (verandah) surrounds the main prayer hall with a width of $3 \mathrm{~m}$ across (Fig. 8). The Serambi, the interchange space between the outside and the interior, is raised at $900 \mathrm{~mm}$ from the ground level with a series of steps at each entrance.

The porch and prayer hall are on the same floor level. The floor for the prayer hall and porch is made of $200 \times 200 \mathrm{~mm}$ ceramic tiles. The foyer of the mosque is used as a place of discussion, socialising and learning. In general, the structure of the mosque (Fig. 9) is a

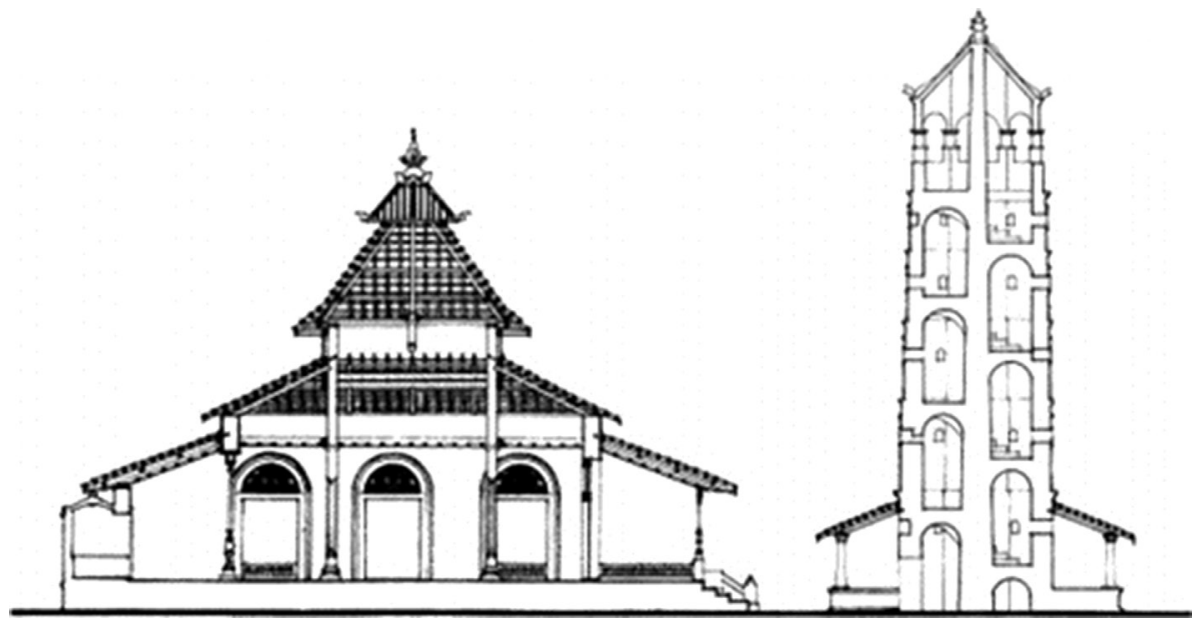

Figure 9: Structure of the mosque. 


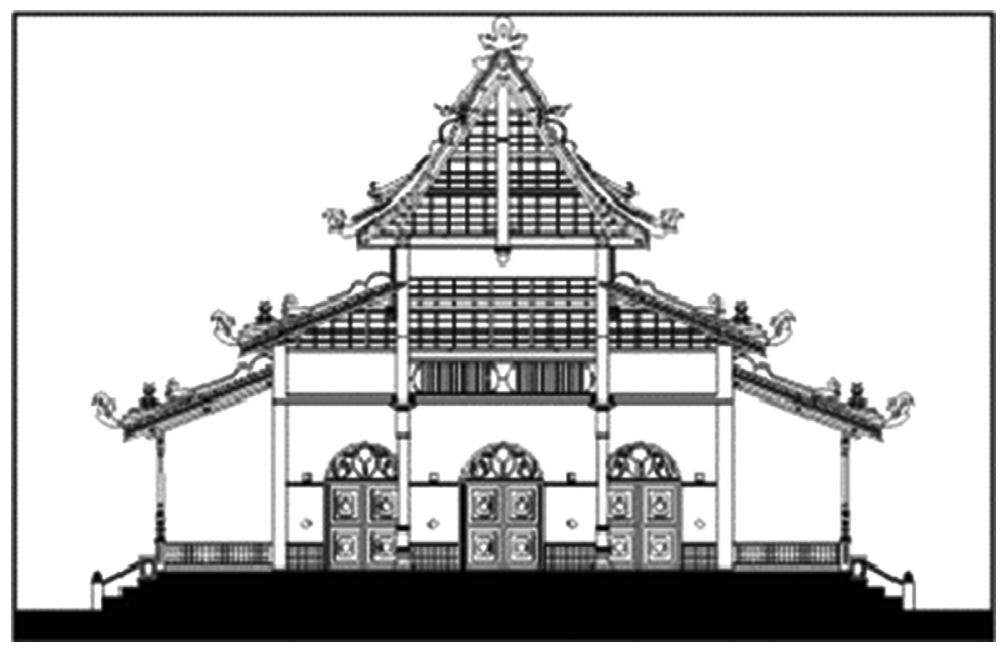

Figure 10: Stacked roof.

combination of post and beam structure and load-bearing walls. The mosque floor is also raised and placed on a brick base. The roof is divided into three main parts, stacked on top of the other. The roof top segment is set at the largest angle, among the three roofs, at $50^{\circ}$. The centre of the roof is set at a slightly sharper angle of $28^{\circ}$ (Fig. 10). The lower part of the roof covers the porch area, supported by stone walls in the prayer hall and outer slope perimeter. This is the sharpest angle among the three parts of the roof set at $19^{\circ}$. The prayer hall was constructed at double height in the middle, while lower in the surrounding space, and had a loft at the top of the ceiling. The attic is bordered with a series of wooden balustrade fences.

In the early stages of Dutch colonisation in Melaka (1641 to 1700), the construction of religious buildings, including the mosque, was allowed. Since the Chinese were known to have knowledge and high skill in stone construction, their involvement was much sought after. Their traditional construction techniques and systems had been adopted. This kind of assimilation is one of the common styles of the formation of the Chinese roof at the roof ridge, observed in the formation of the roof of this mosque (Fig. 11) as seen in Chinese temples. These included the cutting techniques and decorative patches using broken ceramic pieces. The ridge of the Tengkera mosque is similarly decorated like the roof of Chinese temples [26]. The mosque was renovated in early 1910 and responsible businessmen had put on additional Chinese architectural elements. The tower is located south east of the main building outside the main entrance of the mosque. It is separated from the main building (mosque) by about $3 \mathrm{~m}$ and is located along the mosque's axis. The sloping roof that includes the path to the tower connects the two buildings. The mosque tower is $6 \mathrm{~m}$ high and is octagonal in plan (Fig. 12). The ablution pool is located north of the mosque, constructed parallel to the main building and constructed individually (Fig. 13). The roof is supported by a series of iron columns covered with ornate decoration. The cemetery is located on the east side of the tower instead of adjacent to the wall of the qiblah. Most graves used wood and laterite stones, suggesting that these graves may have existed since the beginning of the 18th century, as these are the two most commonly used materials for grave stones during the period. This fact shows that the mosque was built as early as 1728 and it was common to have a 


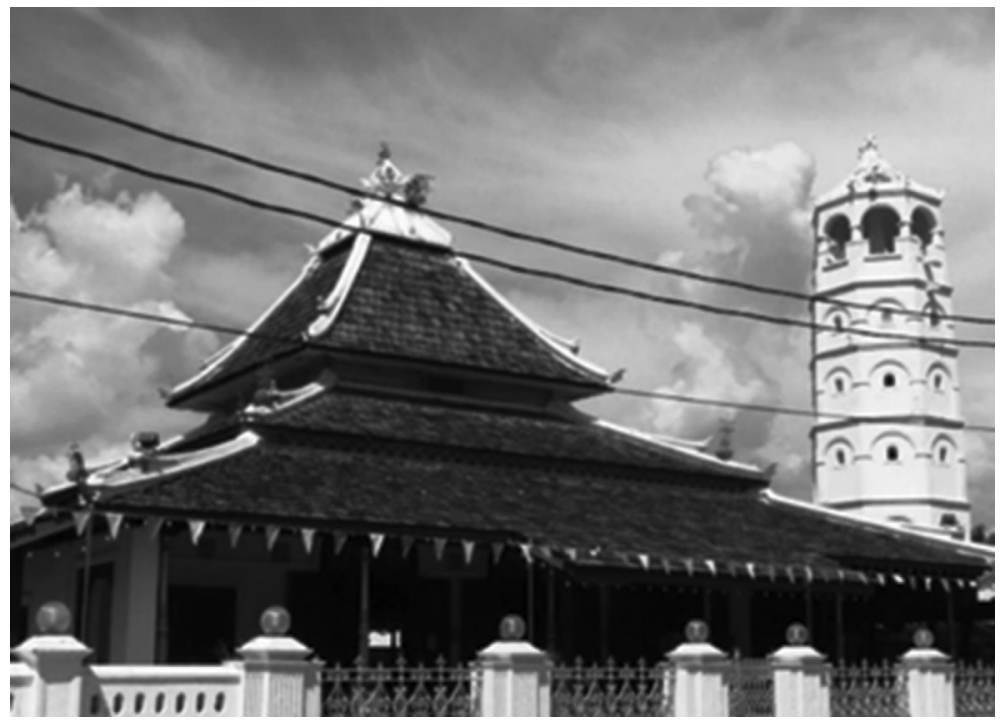

Figure 11: Corrugated ridge roof.

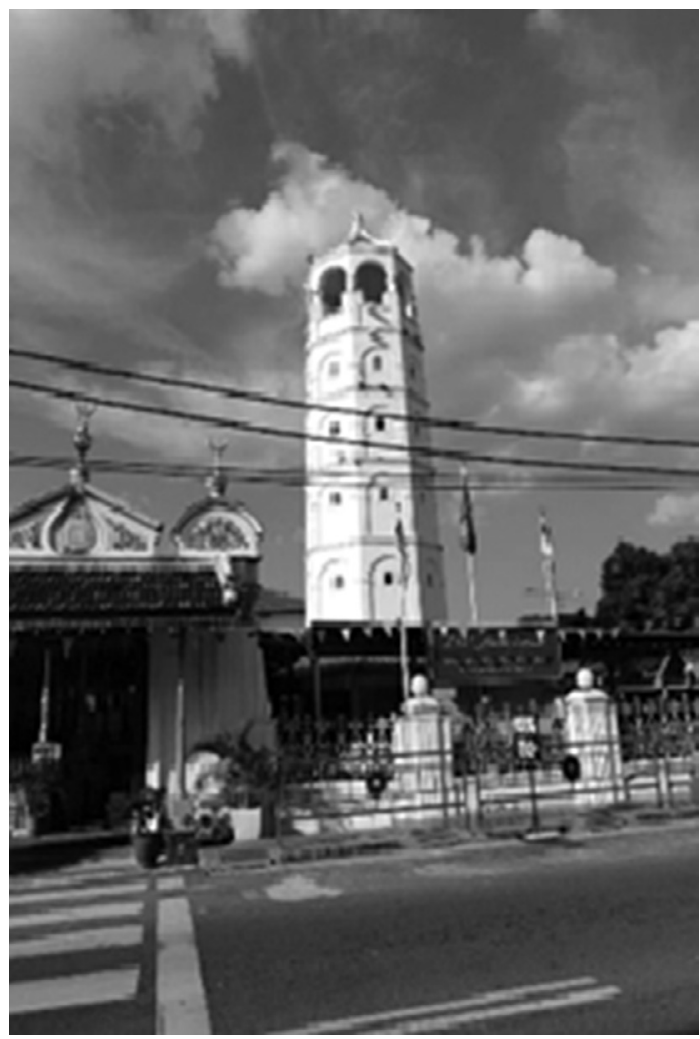

Figure 12: Pagoda tower. 


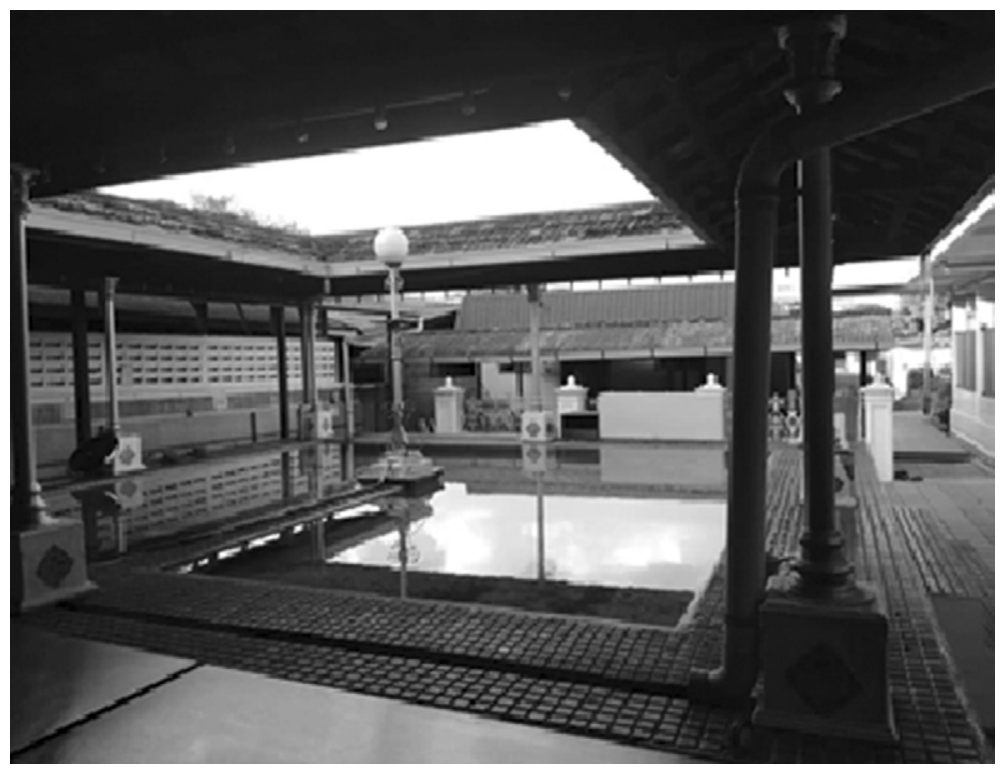

Figure 13: Ablution pool.

cemetery set aside in the same compound when the construction of the mosque occurred. Imam al-Ghazali in Jawahir al-Quran, supported by Sheikh Abdul Samad al-Falimbangi in Saurus Salikin, stated that Islamic Science consists of knowledge of the Shari'a, tariqat and haqiqat [27]. Some scholars argue that the number of roofs over the mosque building such as this mosque represents the level of tasawwuf teaching (i.e. shari'a, tariqat (Sufi doctrine), haqiqat (reality) and maqrifat (wisdom)). They consider a building such as the Demak Mosque to have four levels, of mustaka (symbolising the nature of self-surrender to God at the fourth level) (Fig. 14). This symbolism is a sacred transformation of the mountainous

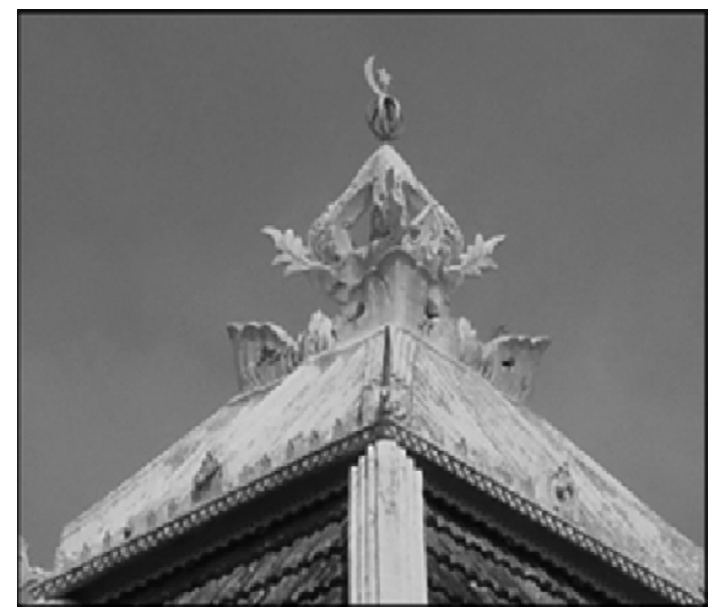

Figure 14: Mustaka. 

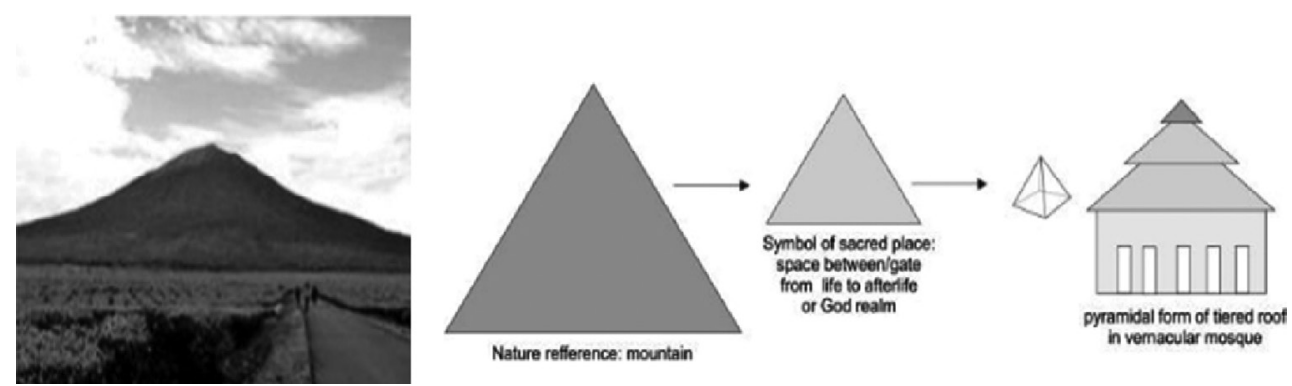

Figure 15: Sacred mountain symbols [31].

nature concept which is a spiritual symbol of spirituality [28, 29]. The Word of God: 'And to God belongs east and west, wherever you are, then there is the face of God. Indeed, Allah is Most Gracious, All-Knowing' (QS.al-Baqarah: 115). This statement links the concept of nature to the concept of space and architecture (Fig. 15). When it comes to a strong level of confidence, one is regarded as a discerning person for the reasons related to semantics, and, through the suluk (mystic) related to divine nature [30]. Therefore, the Shari'a is the question of fiqah (the study of Islamic law) with the essence of maqrifat (wisdom), while tariqat (Sufi doctrine) is the process of understanding the Shari'a to understand haqiqat (reality). This understanding is the value of tasawwuf which is much learned in the science of irfan (knowledge) or tasawwuf.

\section{ANALYSIS OF AESTHETICS}

There are important aesthetic characteristics of the mosque that can influence the ethics of Sufism $[32,33]$. The two known aesthetic concepts are based on formal aesthetics and symbolic aesthetics. A formal aesthetic consists of appearance, proportion, scale, complexity, novelty and lighting aspects $[32,34]$. The formal aesthetic framework structures, according to the aesthetic sciences concerned, are objects expressing more objectively in their own aesthetic symbols through image communication and language and their success is determined by the audience who enjoy it (Fig. 16).
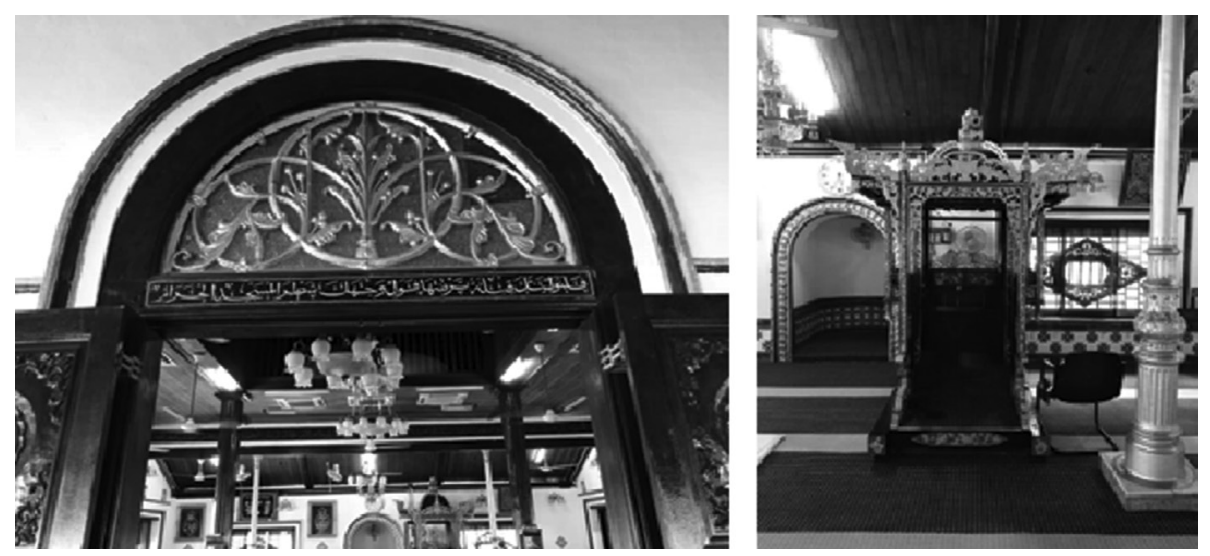

Figure 16: Decorations, calligraphy inscriptions and mimbar. 


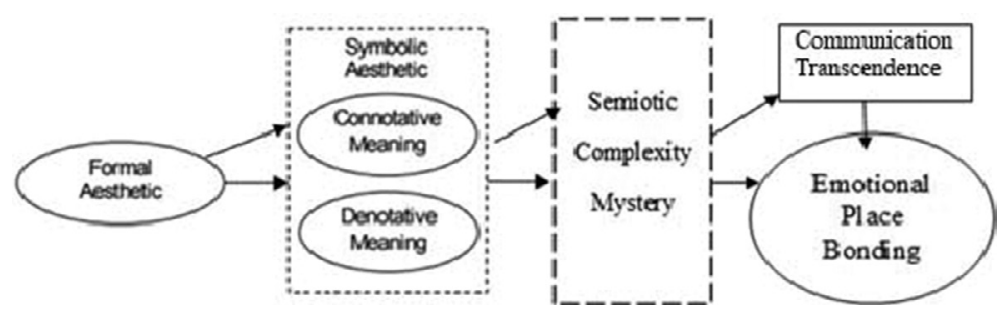

Figure 17: Symbolic framework [31, 38].

Therefore, structuralism relates to the existing relationship between the concepts or symbols associated with local culture and society [35]. Symbolic aesthetics, on the contrary, include dimensions of denotative and connotative meanings. This statement is in line with [36] relating to the concept of socio-semiosis described by [35] that which connects denotative signs such as images, functions and architectural styles, while the connotative signs relate to local culture [36]. The semiotic theory by De Saussure [37] divides semiotics into two (dichotomy) markers and those marked. This marker is seen as physical (complexity) and non-physical (mystery) that can be identified through the form of architectural communications. This sign is seen as a sacred meaning or tasawwur (world view) derived through the concept, function, history or value contained in the work of architecture as a union of emotion through transcendental communication. This communication is Sufistic and can be seen in the mosque's components (Fig. 17).

In the Eliade concept [39] with the theory of 'sacred', there are several components that make the place (mosque) a 'sacred place': Among them is that the place should have the quality or experience felt or interpreted to be distinctive (sensory comfort); then feelings and experiences exist in the place. Therefore, the experience is not subjected to human choice (guidance); the place and what is done there (i.e. rituals), the space is modelled on the pattern (sunnah Prophet Muhammad's (pbuh) teaching); and the place was able to change it (humble). The holy space is the space (or place) that orders khusuk and khuduk (excessive attention), the room can differentiate and divide and alter a person or group so that his life or component is considered meaningful (tranquillity) [40]. In summary, Eliade's theory of interpretation was modified as in the diagram (Fig. 18).

\begin{tabular}{|c|c|}
\hline $\begin{array}{cl}\text { Non-physical aspect (Sacred- } & \text { Sufistic) } \\
\text { 1. } & \text { Sensory Comfort } \\
\text { 2. } & \text { Guidance } \\
\text { 3. } & \text { Ritual } \\
\text { 4. } & \text { Sunnah Model (pbuh) } \\
\text { 5. } & \text { Tawaduk/Humble } \\
\text { 6. } & \text { Khushuk/Focus } \\
\text { 7. } & \text { Tranquility }\end{array}$ & $\begin{array}{cl}\begin{array}{c}\text { Physical Aspect (Sacred } \\
\text { Mosque) }\end{array} \\
\text { 1. } & \text { Serambi/Verandah } \\
\text { 2. } & \text { Prayer hall } \\
\text { 3. } & \text { Ablution Pool } \\
\text { 4. } & \text { Mihrab/Niche } \\
\text { 5. } & \text { Cemetery } \\
\text { 6. } & \text { Qiblah /Orientation } \\
\text { 7. } & \text { Minaret } \\
\text { 8. } & \text { Aesthetic }\end{array}$ \\
\hline
\end{tabular}

Figure 18: The concept of 'Sacred-Sufistic' space. 


\section{SUFISTIC TASAWWUR (WORLD VIEW)}

There are two important values to be understood in this mosque. First, the intrinsic value contained in its aesthetics and second, the extrinsic value seen from the outside. For the intrinsic value, it can usually be seen and understood from the recipient's acceptance, while the extrinsic value can be viewed directly. This means that the value is solely from the psychological reality that must be distinguished strongly from its use, as it is in the tasawwuf (human soul) and not by itself. The value of a person is considered to be in the object until it is proven true, the inherent value that distinguishes between subjective and objective values. Beauty has a very wide dimension and interacts between man and the object (mosque) and between man and God (Allah). The disclosure of beauty in art is based on a particular motivation and with a particular purpose. That motivation can be an experience or reality that changes the values in society, the glory of God and more. The purpose is certainly viewed in terms of the value of human life, human dignity and human use naturally. Tasawwuf is in line with the definition of muktabar (people who practice shari'ah) based on hadith Ihsan 'prayers as if to see Allah swt' [41, 42]. There is a difference of tasawwur related to the terms, meaning and direction related to ethics and morality, as they are synonymous with the meaning of tasawwuf or Sufism. Although it involves attitudes, good and bad deeds, in connection with the construction of mosques, tasawwuf philosophy is seen as relevant in pursuit of mardhatillah (seeking the consent of Allah) as the ultimate goal. The mosque needs to demonstrate a balanced concept of material and spiritual [43].

\section{CONCLUSIONS}

The Melaka Tengkera Mosque has clearly demonstrated the Sufistic influence in its architectural typology. The architecture has portrayed more than physical meaning to the construction and is laced with the teachings of Sufism in almost every one of its architectural components. Deeper meaning of the space planning indicates a simplistic approach to the architecture that is focussed more on faith than decorative features. The simplicity in all its formation creates an emotional outlook to the mosque. There is equality between the construction of emotional bonds and symbolic aesthetics. Some researchers believe emotional bonding is a symbolic connection to the place. For example, the emotional bond itself is recommended to be a 'Sufistic symbolic relationship' between person and place [44, 45], also suggesting that the attachment of the premises provides 'emotional views as well as symbolic of a place' especially the sacred space of the mosque. Therefore, it is reasonable to believe that emotional bonding contributes to the symbolic aesthetic of the mosque. The Islamic arts that have been formed and developed for centuries are facing the threat of the process of acculturation and the mastery of modern artistic values. The typology of this mosque has Sufistic values that can change the fact that the architectural work is a rising experience from physicality to spirituality (transcendental). The purpose of worship is not just the worship of individual self-esteem with the Only One, but how to transform the sacred aesthetic experience of worship into visual objects and ornamentation that are symbolised as symbolic, or tamtsil (a lesson), which is a copy of the idea of ma'na (meaning) into the form of zahir (physical). This traditional architecture typology is a symbolic representation based on the absorption of souls to the real-world communications and transcendental nature. The hybrid components of the shape of the mosque demonstrate the importance of simplicity, harmony and tolerance in maintaining cultural, religious tolerance as well as exhorting fellow human beings. The Melaka Tengkera Mosque has clearly featured the succinct typology of the Wali 
Songo heritage. It will be a great achievement if further studies can be pursued of looking into mosques that are rich with local architecture styles away from the influence of non-Asian characters. The local culture colours represent the true formation of tropical architecture and hence must be championed for achieving the real meaning in the Sufistic teaching.

\section{ACKNOWLEDGEMENTS}

The authors would like to thank Ministry of Higher Education of Malaysia for providing this Research University Individual Grant Scheme (RUi - 1001/PPBGN/8016011) and for providing facilities to carry out the work to support this study.

\section{REFERENCES}

[1] Othman, R., Menelusuri Jejak Kegemilangan Wakaf: Di Mana Peranan Pentadbir. Presented at Seminar Pragmatist 2 - Perkongsian Amalan Terbaik dalam Pengurusan Universiti, Universiti Putra Malaysia: Serdang, 2015.

[2] Bakar, O., Pengaruh Globalisasi Terhadap Peradaban. Jurnal Peradaban. Universiti Malaya: Kuala Lumpur, pp. 1-23, 2008.

[3] Shihab, M.Q., Membumikan Al-Qur'an, Mizan: Bandung, pp. 10-15, 1992.

[4] L. Groat \& Wang, D., Architectural Research Methods, John Wiley and Sons Ltd.: New Jersey, 2013.

[5] Creswell, K.A.C., A Short Account of Early Muslim Architecture II, UK: Clarendon Press: Oxford, pp. 83-87, 1968.

[6] Dickie, J., Allah and Eternity: Mosques, Madrasah and Tombs. Architecture of the Islamic World, ed. G. Michell, Thames \& Hudson Ltd: London, pp. 15-47, 1995.

[7] Creswell, K.A.C., A Short Account of Early Muslim Architecture, Librarie du Liban: Beirut, p. 12, 1958.

[8] Grabar, O., Art and Culture in the Islamic World. Islam: Art and Architecture, ed. M Hattstein \& P. Delius. Tandem Verlag GmbH: Konigswinter, pp. 34-57, 2004.

[9] Mohamad Rasdi, M.T., The Traditional Mosque: The Architectural Heritage of the Malay World, UTM: Skudai, pp. 40-55, 2000.

[10] Frishman, M. \& Khan, Hasan-Uddin, The Mosque: History Architectural Development \& Regional Diversity, Thames \& Hudson Ltd.: London, pp. 9-10, 1994.

[11] Mohamad Rasdi, M.T., Rethinking Islamic Architecture, Strategic Information and Research Development Centre: Petaling Jaya, pp. 1-191, 2010.

[12] Hattstein, M. \& Peter Delius, Islam: Art and Architecture. M Hattstein and P. Delius (eds.). Tandem Verlag GmbH: Konigswinter, pp. 8-33, 2004.

[13] Bosworth, C.E., van Donzel, E., Lewis, B. \& Pellat, Ch., The Encyclopedia of Islam, Vol. VI , EJ. Brill: Leiden, p. 644, 1991.

[14] Othman, S. \& Mohamad, Muzaffar, Ahlul-Bait (Keluarga) Rasulullah SAW dan Kesultanan, Cresent News Sdn. Bhd: Kuala Lumpur, pp. 5-25, 2009.

[15] Mohd. Ali, K., Architecture: Unity of the Sacred and the Profane. Islamic Civilization in The Malay World, Dewan Bahasa dan Pustaka and the Research Centre for Islamic History, Art and Culture: Kuala Lumpur, pp. 245-277, 1997.

[16] O’Neill, H., South East Asia, The Mosque History Architectural Development Regional Diversity, ed. Frishman Martin, Und Khan Hasan Uddin, Thames \& Hudson: London, pp. 225-240, 1994.

[17] Map of Malaysia, Department of Survey and Mapping Malaysia. https://www.jupem. gov.my accessed on: 19 January 2018. 
[18] Vlatseas, S., A History of Malaysian Architecture. Longman, Singapore Publishers Pte Ltd.: Singapore , pp. 39-51, 1990.

[19] Bashah, A.H., Wali Songo: Dengan Perkembangan Islam Di Nusantara, Al-Kafilah Enterprise: Kota Bharu, pp. 1-149, 1996.

[20] Ali, Z., Islamic Art in Southeast Asia - 830 A.D. -1570 A.D, Dewan Bahasa dan Pustaka: Kuala Lumpur, pp. 61-70, 1994.

[21] Gunawan,B.I.,DemakGrandMosque. https://womenindonesia.blogspot.my/search/label/ Traveling accessed on: 19 January 2018.

[22] Ahmad, D.H.M., Sejarah Ringkas Masjid-Masjid Negeri Melaka. Majlis Agama Islam Melaka: Melaka http://www.maim.gov.my/index.php/my accessed on: 19 January 2018.

[23] Mohamad, Ra'alah, The Documentation On The Architectural Features Of Five Oldest Mosques In Melaka Built In 18th Century: Master Thesis, p. 128, 2002.

[24] Omer, S., Studies in the Islamic Built Environment, Kuala Lumpur Research Centre: International Islamic University Malaysia Press: Kuala Lumpur, 2nd ed., pp. 111-145, 2014.

[25] Syed Ariffin, S.A.I., Architectural Conservation in Islam. Universiti Teknologi Malaysia Press: Skudai, pp. 81-108, 2005.

[26] Nasir, A.H., Architecture of the Old Mosques in Southeast Asia. Penerbit Universiti Kebangsaan Malaysia: Bangi, pp. 1-196, 1995.

[27] Mohd Yusof, M.R., Tarekat Naqsyabandiah Al- Khalidiayah Di Malaysia - Satu Analisis Kritis Berdasarkan Al-Quran \& Al-Sunnah. Darul Fikir Sdn. Bhd.: Kuala Lumpur, pp. 1-214, 2004.

[28] J. Jamaludin \& Salura, Purnama, Understanding the Meaning of Triangular Shape in Mosque Architecture in Indonesia, 2018.

[29] Holt, Claire, Art in Indonesia: Continuities and Change, Cornell University Press: New York, 1967).

[30] Nakula, A.M., Senibina Islam - Aplikasi di Malaysia, Pustaka Dian Press: Kota Bharu, pp. 1-93, 1982.

[31] Kaplan, R. \& Kaplan, S., The experience of nature: A psychological perspective, Cambridge University Press: Cambridge, 1989.

[32] Nasar, J.L., Urban Design Aesthetics: The Evaluative Qualities of Building Exteriors. Environment and Behaviour, 26, SAGE Journals, pp. 377-401, 1994.

[33] Steinitz, C., Meaning and Congruence of Urban Form and Activity. Journal of the American Institute of Planners, 34, Taylors and Francis Online, pp. 233-248, 1968.

[34] Lang, J., Understanding Normative Theories of Architecture. Environment and Behaviour, 20, SAGE Journals, pp. 601-632, 1988.

[35] Hawkes, T., Structuralisme and Semiotics, Routledge: London, pp. 8-19, 2003.

[36] Barthes, R., The Semiotic Challenge, Basil Blackwell: London, pp. 1972011988.

[37] Saussure, F., Course in General Linguistics, University of Geneva: Geneva, pp. 65-70, 1916.

[38] Nasar, J. L., New developments in aesthetics for urban design. In G. T. Moore \& R. W. Marans (Eds.), Advances in environment, behavior, and design (Vol. 4, pp. 149-193). Plenum Press: New York.

[39] Eliade Mircea, Patterns in Comparative Religion. Translated by Rosemary Sheed. University of Nebraska Press: Lincoln, 1996 (1958). 
[40] Cave, David. "Eliade's Interpretation of Sacred Space and Its Role Toward the Cultivation of Virtue." In Changing Religious Worlds: The Meaning and End of Eliade, ed. Bryan Rennie. State University of New York Press: Albany, 2001, pp. 235-48.

[41] Al-Attas, S.M.N., The Positive Aspect of Tasawuf: Preliminary Thoughts on an Islamic Philosophy of Science. International Institute of Islamic Thought and Civilization (ISTAC): Kuala Lumpur, pp. 1-12, 1981.

[42] Al-Attas, S.M.N., Islam dan Secularism. International Institute of Islamic Thought and Civilization (ISTAC): Kuala Lumpur, pp. 100-131, 1993.

[43] Awang, R., Falsafah Sains dan Pembangunan ke Arah Dimensi Baru. Penerbit University Teknologi Malaysia: Skudai, pp. 1-40, 2003.

[44] Low, S.M. 1992. Symbolic ties that bind: Place attachment in the plaza. In I. Altman \& S. M. Low (Eds.), Place attachment (pp. 165-185). Plenum Press: New York.

[45] Williams, D.R., Patterson, M.E., Roggenbuck, J.W., \& Watson, A,. Beyond the commodity metaphor: Examining emotional and symbolic attachment to place. Leisure Sciences, 14, 29-46. 